\title{
北海道札幌市でオジロビタキ繁殖か
}

\author{
片山實*・片山慶子*・樋口孝城**
}

\section{Probable Breeding of Red-breasted Flycatcher (Ficedula parva) in Sapporo City, Hokkaido, Japan}

\author{
Minoru Katayama*, Keiko Katayama* and Takashiro Higuchi**
}

\begin{abstract}
Adult male and female Red-breasted Flycatchers (Ficedula parva), and a fledgeling considered to be of the same species were observed at Nishioka Park in Sapporo City, Hokkaido, on July 5, 1997. The fledgeling appeared to have very recently left the nest. The adult female was holding a lepidopterous larva in her beak, and looking out for intruders without any sign of leaving the fledgeling. These facts suggest that breeding had probaby occurred, and this would be the first documented breeding record of this species in Japan.

Key words: Red-breasted Flycatcher, Ficedula parva, Probable breeding, First record, Hokkaido.

キーワード：オジロビタキ, Ficedula parva, 繁殖可能性, 初記録, 北海道.
\end{abstract}

オジロビタキ (Ficedula parva) は日本では稀に見られる旅鳥または冬鳥であり，北海道でも これまでに夏期を含み (Brazil 1991) いくつかの観察記録がある（日本野鳥の会北海道ブロック 支部連合協議会 1991)。繁殖地はカムチャッカ半島，サハリンを含むユーラシア中・北部で (Dement'ev and Gladkov 1954)，日本鳥学会 (1974) は，带種 $F$. p . albicilla を迷鳥として扱って いる。繁殖記録は今までのところない。

著者のうち片山・片山は 1997 年の夏に北海道札幌市豊平区の西岡公園での挆鳥中に，オシ ロビタキ成鳥と巣立ち雛と思われる鳥を観察し，合わせてビデオテープに収録した。成鳥雌の 行動および巣立ち稚らしき個体の存在は, オジロビタキの繁殖の可能性を強く示唆するもので あり，もしそうであればおそらく日本で初めての例となるのでここに報告する。

報告に先立ち, ビデオテープ内容の確認, オジロビタキ繁殖可能性のご教示, 投稿にあたっ ての様々なご指導をいただいた山階鳥類研究所標識研究室の茂田良光氏に深く感謝する。ま た，貴重なご協力，ご助言をいただいた広川淳子氏および日本野鳥の会札幌支部に合わせて感 謝の意を表する。

観察場所は森と池から成る西岡公園内の水源池の上流部である。様々な樹木が生い茂り, 網

Received 25 November 1977, Revised 21 February 1998, Accepted 25 February 1998.

* 干007-0870 北海道札幌过東区伏古 10 条 2 丁目 15-10.

** 北海道医療大学基礎教育部, 干061-0293 北海道石狩郡当別町金沢 1757.

* 10-2-15-10 Fushiko, Higashi-ku, Sapporo, Hokkaido 007-0870, Japan.

** Department of General Education, Health Sciences University of Hokkaido, Tobetsu, Hokkaido 061-0293, Japan. E-mail: higuchi@hoku-iryo-u.ac.jp 

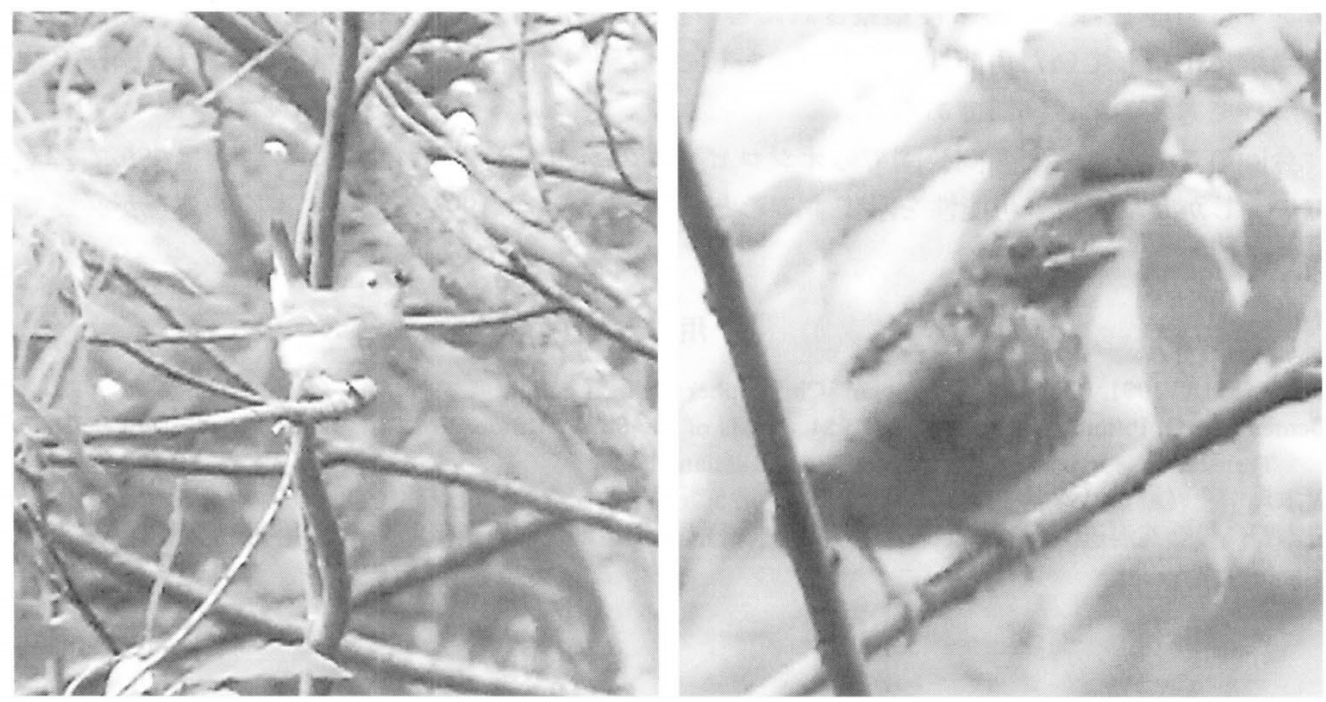

Fig. 1. A female (left) and probable fledgeling (right) of Red-breasted Flycatchers, Sapporo City, 5th July 1997. Image taken from video recording.

状に連なる小川が流れ，湿地带を形成しているが，森林内の一部分という状況である。

1997 年 7 月 5 日の午前 9 時頃, 片山・片山は湿地帯にかけられた木道を歩くうちに, まず成 鳥雌 1 羽を, 続いてすぐ近くで成鳥雄 1 羽を発見した。成鳥雄はすぐにいずれかへ飛び去った が，成鳥雌は鱗翅類の幼虫之思われるものをくわえたまま，近くの枝から枝へと飛び移りを続 けた。その行動には観察者を警戒する父配がうかがわれた。成鳥雌の行動を追っているうち, 成鳥雌の鳴き声に合わせるかのように，巣立ち雛らしき鳥が 1 羽枝上に現われ，ヒッヒッと小 さく鳴きながら慨ねだり行動を示した。成鳥雌からその鳥への給餉は観察できなかったが，そ れは近くにいる観察者を警戒してのこととも推察された。最初の発見から，成鳥雌とその雛ら しき鳥が飛び去るまで約 25 分間観察が続けられ，延べにして約 15 分間の様子がビデオテープ に収められた (Fig. 1)。この雌は尾を頻繁に立てる姿勢をとり, 外側尾羽の基部が白いこと, お よび尾羽の色が黑褐色で背之腰より濃いことから, 近縁で羽色が似るキビタキの雌ではなく, オジロビタキであると確証在得た。また，餌をくわえたまま観察者を警戒し，大きく移動する 気配のない成鳥雌の行動, オジロビタキ巣立雛らしき鳥の出現は, 西岡公園内でのオジロビ 夕キの繁殖の可能性を十分に示唆するあのである。当日の観察およびビデオテープによって あ，その雏がオジロビ夕キ維であると断定することはできず，当地で繁殖しているであろうキ ビ夕キあたりの雛である可能性は残るが，成鳥雌の行動と合わせ考えると，オジロビ夕キ雛と 考えるのが妥当と思われた。また，尾が短いこと，羽色と羽毛の状態および十分とは見えない 飛翔力から，巣立ち後まむないものであり，巣からの移動距離も短いものと推測された。

この観察はただ一度だけの，しかむ短時間のものである。片山・片山はこの観察の翌日およ び 1 週間後に同地点を中心としたかなり広い範井を調查したがオジロビタキを再び観察するこ とはできなかった。西阙公園は札幌市であ有数の探鳥地であり, 年間を通して多くの探鳥家が 訪れる場所であるが，オジロビ夕キの成鳥雌雄が確認されたのは今回が初めてである。オジロ 
ビタキは当地で過去に 2, 3 度観察されたという風聞（広川, 私信）ああり, 1997 年よりあ前か ら当地に飛来していた可能性はあるが，あしそうだとしてあ極めて稀なあのであり，繁殖と結 びつけて考えるのは困難であろう。

今回のことをあって西岡公園でのオジロビタキの繁殖が確認されたということは決して言え ない。しかし, 繁殖の可能性を示唆することは確かであり, 1998 年以降の本格的調査が必要で ある。

\section{引用文献}

Brazil, M. A. 1991. The Birds of Japan. Christopher Helm, London.

Dement'ev, G. P. and Gladkov, N. A. 1954. Birds of the Soviet Union. Vol. VI. Israel Program for Scientic Translations, Jerusalem (Translated from Russian, 1968).

日本鳥学会 (編). 1974. 日本鳥類目録. 改定第 5 版. 学習研究社. 東京.

日本野鳥の会北海道ブロック支部連合協議会（編）。北海道地域別鳥類リスト．野生生物情報セン夕一。札 幌。 